\title{
The Effect of Learning Organization and Organizational Tenure on Innovative Behaviour through Work Engagement as a Mediating Variable
}

\author{
Muhsin $^{1}$, Wisudani Rahmaningtyas ${ }^{2}$, Ahmad Saeroji ${ }^{3}$ \\ \{muhsin@mail.unnes.ac.id ${ }^{1}$, wisudani.rahmaningtyas@mail.unnes.ac.id ${ }^{2}$, saeroji@mail.unnes.ac.id ${ }^{3}$ \} \\ Universitas Negeri Semarang, Indonesia ${ }^{1,2,3}$
}

\begin{abstract}
This study aimed to determine the role of work engagement in mediating the effect of learning organization and organizational tenure on innovative behavior. Phenomena showed that there were 5.6 million teachers in Indonesia; only around $2 \%$ of teachers were innovative, meaning that $98 \%$ of teachers were not innovative. SMK teachers in Central Java consisted of 116 analysis units. The sampling technique used iteration, so that all teachers who were successfully met were the research sample. Data collection techniques used questionnaires. The data used were primary data in the form of answers to questionnaire questions. The results showed that learning organization and organizational tenure had a significant positive effect on Innovate Behavior. Then work engagement was able to mediate the effect of organizational tenure on innovative behavior, but failed to mediate the effect of learning organization on innovative behavior.
\end{abstract}

Keywords: Learning Organization, Organizational Tenure, Innovative Behavior, Work Engagement

\section{Introduction}

Regulation No. 34 of 2018 of Minister of Education and Culture concerning National Education Standards of Vocational High School/Vocational Madrasah Aliyah explains that in order to improve the quality and competitiveness of Indonesian human resources it is necessary to revitalize Vocational High Schools/Vocational Madrasah Aliyah through refinement and alignment of curriculum with competencies according to the needs of graduate users, increasing competence for educators and also included in the component of creativity, explains that the graduate competency standards must have the ability to search for and produce ideas, ways of working, services and innovative work products according to their expertise. Besides that, it must also have the ability to work together to solve problems in carrying out tasks according to their expertise creatively. That is, every education or teacher must be able to accommodate every competency, so to create creative and innovative graduates, they must first begin with teachers who have creativity and innovation. Teachers must continue to update their knowledge, look for new ideas to do their work, use various technologies to improve the quality and effectiveness in carrying out their work [1]. One of the successes of school innovation is determined by the innovative work behavior of teachers [2].

The view that innovation is essential to create competitiveness in organizations has been generally agreed [3]. Innovative behavior is increasingly important for organizational survival. Therefore, many people focus on examining issues such as what affects employees 'innovative 
behavior and how to encourage employees' innovative behavior [4]. To encourage employee innovation habits, organizations must make efforts to encourage employees to produce innovation. The work done by companies in learning to develop to be better is called a learning organization [5]. Rowley [6], organizational learning pays attention to individual learning itself, but that is not enough, but individual learning must be utilized to create organizational learning. $\mathrm{Hu}$ et al. [7]; Wang and Wang [8] revealed that organizational learning abilities and knowledge sharing (other innovative efforts) have been explored as a source of employee innovative behavior because knowledge dissemination functions as an initial idea. Skerlavaj et al. [9], organizational learning culture was found to be a significant predictor of many cultural, product and service (technical) and process (administrative) innovations in Korean companies. Other research also showed a significant positive relationship between team creativity and organizational knowledge creation practices [10].

Besides being influenced by learning organization, innovative behavior is also driven by the length of work tenure (organizational tenure). Personality job fit theory is also related to the theory of compatibility of people with organizations, where this theory accommodates the relationship between organizational tenure and innovative behavior. This theory shows that an organizational tenure can promote innovative employee behavior. Liu et al. [11] defined the length of service of an organization as the length of time someone holds a job in an organization Wright and Bonett [12] so that it can affect employee attitudes, behavior, and performance. Furthermore, he explained that through the accumulation of organizational tenure, one might have more work experience so that it is more innovative in developing strategies for organizational development. Individuals with longer tenure are generally those who perform well to survive the friction process [13]. In addition, tenure in an organization causes employees to get projects that are relevant and specific, because they have extensive organizational knowledge to facilitate performance [14].

Phenomenon on the ground showed that the quality of teachers in producing innovations was low; the data revealed that Indonesia ranked 4th- last in global talent competitiveness index 2019. Singapore ranked first with a score of 77.27. The next rank was followed by Malaysia (58.62), Brunei Darussalam (49.91) and the Philippines (40.94). Meanwhile, Indonesia ranked sixth with a score of 38,61 .

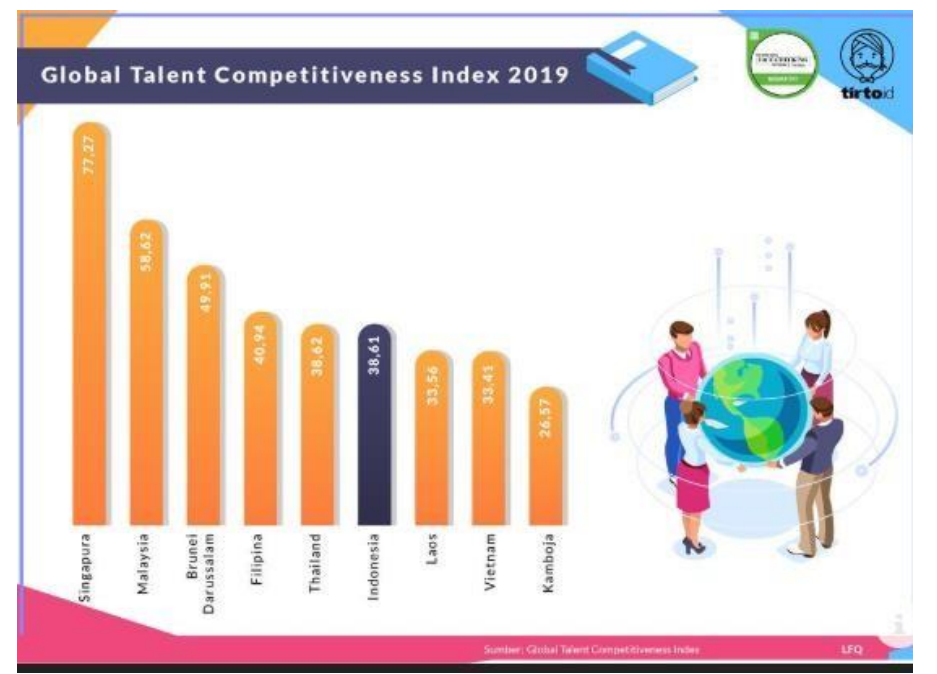

Fig. 1. Global Talent Competitiveness Index 2019 (Secondary data processed, 2019). 
In addition, the results of teacher competency tests in Indonesia are still far from the average figure set by the government, in 2019/2020 the government set competency standards for educators, especially teachers reaching a score of 80.00 , but in reality, that number had not been reached in all provinces in Indonesia. The data showed that the average national teacher competency score was 56.69. The average was measured from a variety of teacher competencies consisting of social competencies, personality competencies, knowledge competencies and skills competencies. The low number also illustrated the low competency of teachers so it had implications for the lack of innovation created. The education expert at Universitas Muhammadiyah Surakarta (UMS), Prof. Dr. Tjipto Subadi, revealed, the quality of education in Indonesia is among the lowest in the world, among the causes is the teacher factor in the national education system. Teachers in Indonesia in general, are accustomed to working alone, teachers who are creative and innovative in teaching do not affect other teachers, the egoism of teachers is relatively high and other contributing factors include the teacher coaching model. It is strengthened by the narrative of Central Java DPRD Commission E member Yudi Indras Wiendarto said the problem of education in Central Java is not only that.

Based on data from the Directorate General of Secondary Education of the Ministry of Education and Culture, the achievement of SMA/SMK in Central Java referring to 8 National Education Standards (SNP) declined down. The most concerning was the Standard of Education and Educator Staff 3.71-4.51-3.8. Likewise with the achievement of SNP SMK, the results also showed there were 5.6 million teachers in Indonesia, only around $2 \%$ of teachers were innovative, meaning that $98 \%$ of teachers were not innovative.

\section{Research Method}

The population in this study was lecturers in state university in Central Java. The sample selection in this study used the iteration method, so that a sample of 116 Vocational High School teachers was obtained. The variables used in this study were innovative behavior as the dependent variable, organizational flow and organizational tenure as the independent variable, and work engagement as a moderating variable. Data collection techniques used a questionnaire while the analysis tool used descriptive analysis and moderated regression analysis.

\section{Results and Discussion}

\subsection{Descriptive Statistics}

Table 1. Result of Descriptive Statistics Descriptive Statistics

\begin{tabular}{lccccc}
\hline \multicolumn{1}{c}{$\mathrm{N}$} & \multicolumn{2}{c}{ Minimum } & Maximum & Mean & Std. Deviation \\
\hline Learning Organization & 120 & 34.00 & 70.00 & 54.7333 & 8.12066 \\
Organizational Tenure & 120 & 18.00 & 30.00 & 24.7667 & 3.35249 \\
Work Engagement & 120 & 26.00 & 50.00 & 40.9250 & 5.61385 \\
Innovation Behavior & 120 & 30.00 & 50.00 & 41.4667 & 5.14322 \\
Valid N (listwise) & 120 & & & & \\
\hline
\end{tabular}

Source: Primary data processed, 2020 
Results of descriptive analysis test showed distribution of research data in detail was explained in Table 1. The results indicated that the variable of learning organization had a minimum value of respondents from the questionnaire answers of 34 and a maximum value of 70. The mean value was 54.7333 with a standard deviation or data distribution of 8.12066. Variable Organizational tenure had a mean value of 24.7667 with a standard deviation of 3.35249 , in addition the mediation variable namely work engagement had a value of 40.9250 and a standard deviation of 5.61385. Finally, the innovative behavior variable got a mean of 41.4667 and the standard deviation value was 5.14322. The results of the four variables in the calculation of descriptive statistics indicated that the mean was greater than the standard deviation. This showed that there was a good representation for data distribution.

Before testing hypotheses, classical assumptions were tested, which included normality test of the Kolmogorov Smirnov and P-Plot, multicollinearity test, and heteroscedasticity test. Based on the Kolmogorov-Smirnov One-Sample test, it can be seen that the data was avoided from the normality problem where the significance value indicated a value of 0.169 . The results of multicollinearity test showed that all variables used had tolerance values of more than 0.1 and VIF values of less than 10 therefore it can be said that there was no multicollinearity in the model used. The output of the park test used to test the symptoms of heteroscedasticity showed a significance value of more than 0.05 from each variable, therefore it can be concluded that the model was avoided from heteroscedasticity. Then in the third model a moderation test was carried out and the results of the description was shown in table 2.

Table 2. Moderation Test

\section{Coefficients $^{\mathbf{a}}$}

\begin{tabular}{|c|c|c|c|c|c|c|c|c|}
\hline \multirow{2}{*}{\multicolumn{2}{|c|}{ Model }} & \multicolumn{2}{|c|}{$\begin{array}{l}\text { Unstandardized } \\
\text { Coefficients }\end{array}$} & \multicolumn{3}{|c|}{$\begin{array}{c}\text { Standardized } \\
\text { Coefficients }\end{array}$} & \multicolumn{2}{|c|}{$\begin{array}{l}\text { Collinearity } \\
\text { Statistics }\end{array}$} \\
\hline & & B & Std. Error & Beta & $\mathrm{T}$ & Sig. & Tolerance & VIF \\
\hline \multirow[t]{3}{*}{1} & (Constant) & 23.553 & 1.243 & & 18.942 & .000 & & \\
\hline & $\mathrm{X} 1 . \mathrm{Z}$ & .000 & .001 & -.036 & -.536 & .593 & .560 & 1.785 \\
\hline & X2.Z & .018 & .001 & .865 & 12.956 & .000 & .560 & 1.785 \\
\hline \multicolumn{9}{|c|}{ a. Dependent Variable: Innovation Behavior } \\
\hline
\end{tabular}

Source: Primary data processed, 2020.

In table 2. It was explained that the effect of learning organizations through moderating variable, namely work engagement on innovative behavior was not significant because the beta value of -0.036 with a significance of 0.593 . Then the effect of organizational tenure on innovative behavior through work engagement had a beta value of 0.865 with a significance of 0,000 , which means significant. Then the results of hypothesis testing can be seen in Table 3 .

Table 3. Results of Hypothesis Test

\begin{tabular}{clcccc}
\hline No & \multicolumn{1}{c}{ Hypothesis } & Beta & Sig. & A & Results \\
\hline 1. $\begin{array}{l}\text { Learning Organization has a significant positive } \\
\text { effect on innovative behavior }\end{array}$ & 0,114 & 0,020 & 0,05 & Accepted \\
2. $\begin{array}{l}\text { Organizational Tenure has a significant positive } \\
\text { effect on innovative behavior }\end{array}$ & 0,832 & 0,000 & 0,05 & Accepted \\
3. $\begin{array}{l}\text { Learning Organization has a significant positive } \\
\text { effect on work Engagement }\end{array}$ & 0,083 & 0,362 & 0,05 & Accepted \\
4. $\begin{array}{l}\text { Organizational tenure has a significant positive } \\
\text { effect on work engagement }\end{array}$ & 0,254 & 0,006 & 0,05 & Accepted
\end{tabular}


5. Learning Organization did not have an effect on innovative behavior through work engagement

$-0,036 \quad 0,593 \quad 0,05 \quad$ Rejected

6. Organizational Tenure has a significant positive effect on innovative behavior through work 0,865 0,000 0,05 Accepted engagement

Source: Primary data processed, 2020.

\subsection{Effect of Learning Organization on Innovative Behavior}

The results showed a significant effect of learning organization on innovative behavior. This can be interpreted as the higher a person did learning organization, it would increase the innovation produced. According to Marquardt and Reynolds [15] learning is a process carried out by individuals in their efforts to acquire new knowledge and insights to change their behavior and actions. Meanwhile, the characteristics of LO are the existence of a supportive climate, learning culture, human resource development strategies, and putting the organization in a process of continuous transformation. Also, it was strengthened by Fahey [16] which stated that learning is not just knowledge creation but also uses it for decision-making and action guidance. The results of this study were in line with a number of expert opinions which suggested that learning is an attempt to construct new insights and will lead to action. So, it was clear that the more often a person did learn, the more his ability to develop new insights and produce innovative behavior.

The education staff or teacher was a determining factor in the successful achievement of learning objectives. The current phenomenon of the government has encouraged teachers, especially the Vocational High School (SMK) to innovate in learning. A teacher's creative thoughts or ideas were needed to be able to change the learning scenario to be more interesting, effective and efficient, while simultaneously encouraging students to actively participate in learning activities. Conditions in the midst of a pandemic such as now encouraged teachers to do learning, for example they took part in the socialization of distance learning with technologybased media, teachers were also increasingly intense in attending seminars and training in the use of online learning media through webinar activities. With more intense teacher learning, innovations would emerge in teaching and learning activities. Schools that implemented or required teachers to use technology to share information can stimulate teachers to exchange ideas and bring up innovative actions in organizations.

Learning organization as an effort taken by the organization in the context of how to learn about new things related to the work of teachers, for example in terms of approaches, methods, learning models used in learning activities. Besides learning organization was also an effort to motivate teachers to find new ideas that would contribute to the school's reputation. Thus, it was very possible for organizations to trigger the habit of innovating for organizational members by encouraging innovative behavior of organizational members [17]. Prakoso [18] revealed that the results of testing using partial least square (PLS) showed that the learning organization had a positive effect on innovative behavior. This was in line with the findings in this study which showed the same thing. Even this result was reinforced again by Anshar [19] resulting in the finding that visionary leadership and learning organizations had a direct and positive effect on innovative behavior.

\subsection{Effect of Organizational Tenure on Innovative Behavior}

The results showed a significant effect of organizational tenure on innovative behavior. Organizational tenure was about the period of employment of employees. The working period 
is the whole lesson learned by someone from the events that are passed in his life journey. The working period was the period of time or length of time someone works in an agency, office and so on [20]. Meanwhile, work period or work experience is those who are deemed capable of carrying out their duties which will be given in addition to intelligence abilities which are also the basis for further consideration. From the opinion above, it can be concluded that the work period or work experience was the expertise or ability possessed by someone in a field of work obtained by learning in a certain period of time which was certainly seen from the ability of intelligence, both experience that came from outside the company or from within the company.

Organizational tenure referred to the length of work held by someone in an organization. Employees who had different organizational tenure can differ from each other in terms of psychological characteristics, cognitive level, experience and career strategies [11][21][22]. These theories indicate that organizational tenure "can" promote innovative employee behavior, but organizational tenure is a variable in the personality trait of new or old employee attributes. So that the findings in this study were in line with the opinions of experts who revealed that organizational tenure contributed to the formation of innovative employee behavior. Organizational tenure as a moderating variable affected the innovative behavior of employees.

The phenomenon on the ground showed that currently the demands of teachers to innovate were very high, the more people work, the more they would produce innovation, because they had more work experience. The results of this study also revealed that the more senior, the more innovative the teachers were. Many outstanding teachers came from those who already had a lot of experience in developing creative ideas. In addition, they had gone through many problems at work, so that the ability to find solutions to problems and better decision-making skills were formed, so that from those experiences and abilities, those teachers who had long worked would tend to be more creative and innovative at work.

\subsection{Effect of Learning Organization on Work Engagement}

The research findings showed that learning organization had a positive and significant effect on work engagement. Work engagement is a statement of mind about work that is intact and positive, where this is shown through passion/ vigor, dedication and absorption in work [23][24]. In essence, work engagement sees how employees carry out their work; whether as something that stimulates and makes active, and something that makes them really willing to be loyal or provides full time and effort (the vigor component); as something significant and meaningful (dedication); and as something that is exciting and makes, they are truly able to concentrate (absorption) [25].

Khan [26] described an employee who is engaged as a person who is physically, cognitively and emotionally fully connected to his work. The same thing was reinforced by the statement of Bakker et al. [27] which stated that engaged employees have a positive attitude and a high level of activity, they are able to create positive feedback for themselves, in terms of appreciation, recognition, and success. They also enjoy a variety of activities outside of work, so that it is different from workaholics who work hard because of an impulse in themselves that cannot be held, for them to work is fun [27]. So, it can be said that indirectly when an employee is involved in an organization as a whole, then he has had a learning effort in the organization very well, therefore the findings in this study were in line with some of the expert opinions above.

The results showed that a good learning organization at PT Pertamina MOR V Jatim Balinus could influence the increase in employee engagement work [18]. Besides that, research 
also showed a significant positive relationship between team creativity and organizational knowledge creation practices [10]. In addition, Tseng [28] and Atak [29] found that learning organization culture made a positive impact on employee commitment to the organization. Employees involved were found to display more proactive behavior [30].

The greatest demand and task of a teacher was that he must be willing to study wherever and whenever he had to be able to adjust his abilities to the current demands. The intensity of the teacher in doing learning would encourage better involvement. At present, in a pandemic situation like this, the teacher must learn continuously to adapt the learning scenario to the needs and preferences of the students, while also the involvement of the teacher in the teaching and learning process was urgently needed. Thus, when a teacher had high learning intensity, it would increase his involvement in the work.

\subsection{Effect of Organizational Tenure on Work Engagement}

The results of hypothesis testing indicated that organizational tenure had a positive and significant effect on work engagement. Companies were no longer only looking for prospective employees who had above average capabilities, but they were also looking for prospective employees who were able to invest themselves to be fully involved in work, proactive, and had a high commitment to quality standards of performance [27].

A long period of work would make an employee feel more at home or tend to have a sense of work attachment in an organization or company, this was because they had adapted to the work environment long enough so that someone would feel comfortable with their work. Other causes were also due to policies from agencies or companies regarding life insurance in old age [31]. They also needed employees who can be tied to their work [32]. Various expert opinions explained the relationship and direction between organizational tenure and work engagement. Kurniawati (2014) produced a finding that it can be seen that the correlation coefficient between tenure and job engagement was 0.653. Significance test showed the results of 0,000 (p 0.01$)$ which means that the correlation of the two variables was very significant.

Each employee had a different service period, then from different service periods people often mentioned it in terms of senior and junior. Every employee who had a long service life, tend to be involved in various jobs. That was caused by the length of service of an employee that would affect his performance. They were considered to have better ability, more experience and ability to solve problems more wisely. So directly they also had a very high work involvement. Like a teacher, for those who had a long working period would get more teaching hours, be involved in various school activities and be more trusted. They were involved in more work than teachers with only a few years of service.

\subsection{Effect of Learning Organization on Innovative Behavior with Work Engagement as a Moderating Variable}

The results showed that work engagement was unable to mediate the effect of learning organizations on innovative behavior. Although someone had learned new things, then had been involved in an organization, but not yet able to implement the ideas they had freely. Often in an organization an employee who was diligent and often involved in many organizational activities actually got pressure from many parties. For example, cases of unfair competition in an organization encouraged someone to corner other employees, from this phenomenon someone would feel pressured, so that even though he or she was doing good learning activities, they had a high work involvement, but not necessarily able to encourage innovative behavior to employees. Kahn [33] stated that there were three psychological conditions related to the 
formation of attachment at work, namely meaning, security, and willingness. It was clear here that security was one of the determinants of employee involvement in the workplace.

\subsection{Effect of Organizational Tenure on Innovative Behavior with Work Engagement as a Moderating Variable}

The results revealed that work engagement was able to moderate the effect of organizational tenure on innovative behavior. Organizational tenure referred to the length of work held by a person in an organization or can also be referred to as the length of service of an employee. Employees who had different organizational tenure can differ from one another from psychological characteristics, cognitive level, experience and career strategies [21][22]. The longer the work period of a person, the more they were involved in his organization. So that involvement would build a lot of knowledge and mature, skills and experience that can be used to support the formation of creative ideas in employees. Even though so many studies focused on this area, there were no consistent conclusions about the problem of how the tenure of an organization influenced employees' innovative behavior and what the authenticity of the relationship was. Literature showed a positive thing [21][34].

Besides that, Liu et al. [11] said the results showed that organizational tenure was a key factor influencing employee job involvement, job satisfaction and innovative behavior. Liu et al. [11] human resources tended to increase with the accumulation of organizational tenure, which was beneficial for employees to make innovation more effective in their contributions. So, it can be concluded that one's work period played an important role in encouraging creative ideas so as to produce innovative behavior. In addition, work tenure also increased the work involvement of employees, which then had implications for the formation of innovative behavior.

\section{Conclusion}

The conclusion of this study was that learning organization and organizational tenure had a significant positive effect on innovate behavior and work engagement was not able to mediate the effect of learning organizations on innovative behavior, but was able to be mediation between organizational tenure and innovative behavior. Based on this research a teacher was expected to be able to produce innovation, for example innovation in teaching and learning activities. The intended innovation can be in the form of learning methods, models and learning scenarios based on the needs and preferences of students. Besides that, innovation in the development of instructional media was also important to be mastered by the teacher. A suggestion for further research is the use of other measurements in the variable work engagement, because in this study work engagement was not able to moderate the effect of learning organization on innovative behavior.

\section{References}

[1] O. Kurniasih, "Pengaruh structural empowerment, leader empowerment, dan psychological empowerment terhadap innovative behavior guru di SMK 10 Nopember Jakarta." Universtas Pelita Harapan, 2019.

[2] P. Gkorezis, "Principal empowering leadership and teacher innovative behavior: A moderated mediation model," Int. J. Educ. Manag., 2016. 
[3] X. Zhang and K. M. Bartol, "The influence of creative process engagement on employee creative performance and overall job performance: A curvilinear assessment.," J. Appl. Psychol., vol. 95, no. 5 , p. $862,2010$.

[4] F. Yuan and R. W. Woodman, "Innovative behavior in the workplace: The role of performance and image outcome expectations," Acad. Manag. J., vol. 53, no. 2, pp. 323-342, 2010.

[5] A. Örtenblad, "On differences between organizational learning and learning organization," Learn. Organ., 2001.

[6] J. Rowley, "Creating a learning organisation in higher education," Ind. Commer. Train., 1998.

[7] M.-L. M. Hu, J.-S. Horng, and Y.-H. C. Sun, "Hospitality teams: Knowledge sharing and service innovation performance," Tour. Manag., vol. 30, no. 1, pp. 41-50, 2009.

[8] Z. Wang and N. Wang, "Knowledge sharing, innovation and firm performance," Expert Syst. Appl., vol. 39, no. 10, pp. 8899-8908, 2012.

[9] M. Škerlavaj, J. H. Song, and Y. Lee, "Organizational learning culture, innovative culture and innovations in South Korean firms," Expert Syst. Appl., vol. 37, no. 9, pp. 6390-6403, 2010.

[10] S. W. Yoon, J. H. Song, D. H. Lim, and B.-K. Joo, "Structural determinants of team performance: The mutual influences of learning culture, creativity, and knowledge," Hum. Resour. Dev. Int., vol. 13, no. 3, pp. 249-264, 2010.

[11] Z. Liu, L. Ge, and W. Peng, "How organizational tenure affects innovative behavior? The role of culture difference and status determinants," Nankai Bus. Rev. Int., 2016.

[12] T. A. Wright and D. G. Bonett, "The moderating effects of employee tenure on the relation between organizational commitment and job performance: a meta-analysis.," J. Appl. Psychol., vol. 87 , no. 6 , p. $1183,2002$.

[13] B. Schneider, H. W. Goldstiein, and D. B. Smith, "The ASA framework: An update," Pers. Psychol., vol. 48, no. 4, pp. 747-773, 1995.

[14] N. Uppal, "Uncovering curvilinearity in the organizational tenure-job performance relationship," Pers. Rev., 2017.

[15] M. J. Marquardt, M. Marquardt, and A. Reynolds, The global learning organization. Irwin Professional Pub, 1994.

[16] L. Fahey and L. Prusak, "The eleven deadliest sins of knowledge management," Calif. Manage. Rev., vol. 40, no. 3, pp. 265-276, 1998.

[17] Y. Gong, J.-C. Huang, and J.-L. Farh, "Employee learning orientation, transformational leadership, and employee creativity: The mediating role of employee creative self-efficacy," Acad. Manag. J., vol. 52, no. 4, pp. 765-778, 2009.

[18] W. D. Prakoso, "PENGARUH KUALITAS PRODUK, KUALITAS PELAYANAN, DAN GAYA HIDUP TERHADAP LOYALITAS PELANGGAN STARBUCKS CENTRAL PARK MALL." Universitas Mercu Buana, 2017.

[19] M. Anshar, "The impact of visionary leadership, learning organization and innovative behavior to performance of customs and excise functional," Ijhcm (International J. Hum. Cap. Manag., vol. 1 , no. 02 , pp. 52-60, 2017.

[20] S. Alwi, "Manajemen sumber daya manusia strategi keunggulan kompetitif," BPFE, yogyakarta, 2001.

[21] T. W. H. Ng and D. C. Feldman, "A meta-analysis of the relationships of age and tenure with innovation-related behaviour," J. Occup. Organ. Psychol., vol. 86, no. 4, pp. 585-616, 2013.

[22] D. E. Super, "A life-span, life-space approach to career development," J. Vocat. Behav., vol. 16, no. 3, pp. 282-298, 1980.

[23] W. B. Schaufeli and A. B. Bakker, "Defining and measuring work engagement: Bringing clarity to the concept," Work Engagem. A Handb. Essent. theory Res., vol. 12, pp. 10-24, 2010.

[24] W. B. Schaufeli, M. Salanova, V. González-Romá, and A. B. Bakker, "The measurement of engagement and burnout: A two sample confirmatory factor analytic approach," J. Happiness Stud., vol. 3, no. 1, pp. 71-92, 2002.

[25] A. B. Bakker, W. B. Schaufeli, M. P. Leiter, and T. W. Taris, "Work engagement: An emerging concept in occupational health psychology," Work Stress, vol. 22, no. 3, pp. 187-200, 2008.

[26] D. Mathumbu and N. Dodd, "Perceived organisational support, work engagement and 
organisational citizenship behaviour of nurses at Victoria Hospital," J. Psychol., vol. 4, no. 2, pp. 87-93, 2013.

[27] A. B. Bakker, “An evidence-based model of work engagement," Curr. Dir. Psychol. Sci., vol. 20, no. 4 , pp. $265-269,2011$

[28] C.-C. Tseng, "The influence of strategic learning practices on employee commitment," Tseng, C.(2011). Influ. Strateg. Learn. Pract. Empl. commitment. J. Multidiscip. Res., vol. 3, no. 1, pp. 5-23, 2011.

[29] M. Atak, "A research on the relation between organizational commitment and learning organization," African J. Bus. Manag., vol. 5, no. 14, pp. 5612-5616, 2011.

[30] S. Sonnentag, "Recovery, work engagement, and proactive behavior: a new look at the interface between nonwork and work.," J. Appl. Psychol., vol. 88, no. 3, p. 518, 2003.

[31] A. Kinicki and R. Kreitner, "Organizational Behavior.[University of Phoenix Custom Edition etext]," New York McGraw-Hill. Retrieved June, vol. 28, p. 2010, 2004.

[32] A. B. Bakker and M. P. Leiter, Work engagement: A handbook of essential theory and research. Psychology press, 2010.

[33] W. A. Kahn, "Psychological conditions of personal engagement and disengagement at work," Acad. Manag. J., vol. 33, no. 4, pp. 692-724, 1990.

[34] M. P. McEnrue, "Length of experience and the performance of managers in the establishment phase of their careers," Acad. Manag. J., vol. 31, no. 1, pp. 175-185, 1988. 